\title{
Educação em saúde: uma reflexão histórica de suas práticas
}

\author{
Health education: a historical reflection of its practices
}

Cristiane $\mathrm{M}$ aria da Costa Silva ${ }^{1}$

M arcelo de Castro $M$ eneghim ${ }^{1}$

Antonio Carlos Pereira ${ }^{1}$

Fábio Luiz M ialhe ${ }^{1}$

Abstract This text aims to contextualize the transformations occurred in the practice of health education since the political scenario in the end of $19^{\text {th }}$ century, when the first extended initiatives of the Brazilian State in the health field were organized, until the creation of the Brazilian U nified H ealth System.

Key words Health education, State, Popular participation
Resumo Este texto procura contextualizar as transformações ocorridas nas práticas de educação em saúde desde o cenário político no final do século XIX, quando se organizaram as primeiras iniciativas ampliadas do Estado brasileiro no campo da saúde, até a criação do Sistema Ú nico de Saúde.

Palavras-chave Educação em saúde, Estado, Participação popular 
Introdução

A relação entre a educação, saúde e suas práticas é condicionada por dimensões estruturais complexas que precisam deuma análise histórica para sua maior compreensãoํ. No plano histórico, a sucessão de modelos de educação aplicadosà área da saúde pública não significa um sequência evolutiva; antes, é uma descrição da prática dominante em certos períodos em relação aos proble mas de saúde destacados para intervenção, visando à manutenção da hegemonia da classe dominante ${ }^{2,3}$. Desta forma, verifica-se que as atividades desenvolvidas eram e ainda são orientadas pelas concepções de saúde e de educação em saúde vigentes em cada período histórico e pelos modelos de atenção implantados nos serviços, na busca da manutenção da saúde da mão de obra trabalhadora para fins capitalistas.

A ideia de uma pedagogia higiênica organizou-se pela primeira vez no Brasil na segunda metade do século XIX, sendo a população-alvo dessa prática as famílias da el ite ${ }^{1}$. Iniciava-se uma cruzada para europeizar os costumes e urbanizar os hábitos da elite brasileira, com o objetivo de transformar o perfil sanitário da antiga família colonial, composta de agregados, escravos, domésticos e serviçais, em uma instituição conjugal e nuclear marcada pelo sentimento de privacidade ${ }^{1,4}$. A intenção maior era legitimar a classe social por meio de seus atributos físicos, psíquicos e sexuais. Tal fato alimentou, indiretamente, ideologias racistas e preconceituosas, servindo para a manutenção da exploração das classes subalternas, em nome da superioridade racial e social das elites brancas 4 .

Para a outra parcela da população, restava apenas o instrumento de coerção da polícia, do recrutamento militar ou dos espaços de segregação higiênica das prisões ${ }^{5}$. Nestaépoca, ainda não interessava ao Estado mudar o padrão sanitário das camadas chamadas "desclassificadas". Segundo Eymard Mourão Vasconcelos ${ }^{1}$, as populações periféricas das grandes cidades despertavam preocupações médicas apenas quando a imundície de suas ruas e seus quintais era considerada foco de propagação de doenças pestilentas causadoras de epidemias.

Já no final do século XIX e início do século $X X$, o Estado viu-se obrigado a estruturar as primeiras intervenções sistemáticas de educação em saúde ampliadas às classes populares ${ }^{6}$, justamente para combater as epidemias de febre amarela, varíola e peste, que estavam trazendo grandes transtornos para a exportação de café. Estas epi- demias ameaçavam os interesses do modelo econômico agrário-exportador, pois em decorrência destas, vários navios mercantes, sob bandeiras estrangeiras, vinham deixando defazer escala no Brasil, passando ao largo da costa brasileira e aportando diretamente na Argentina ${ }^{1,5}$. Desta forma, o foco de atenção do governo brasileiro voltou-se, estrategicamente, aos chamados espaços de circulação de mercadorias, ou seja, as estradas e portos, principalmente os do Rio de Janeiro e São Paulo?.

Como estratégia de atuação, as instituiç̧ões de saúde se organizavam a partir do modelo campanhista, de inspiração bélica, para combater as epidemias, baseadas em experiências dos serviços de saúde dos exércitos coloniais, mantendo a estrutura e o modo de operações militares ${ }^{8}$. Este modelo concentrava fortemente as decisões nas mãos de tecnocratas e adotava um modelo repressivo de intervenção médica nos corpos individuais e sociais 9 . As práticas de saúde eram extremamente autoritárias. N este sentido, houve importante influência da doutrina denominada de polícia médica, desenvolvida na Alemanha de Bismarck, na segunda metade do século XIX, a qual partia do pressuposto de que ao Estado cabia assegurar bem-estar e segurança ao povo, mesmo contrariando interesses individuais, justificando-se assim o controle coercivo dos problemas sanitários como mecanismo de assegurar a defesa dos interesses gerais da nação $0^{1,5}$. Foi então criada no Brasil a polícia sanitária e suas ações eram baseadas no discurso da higiene, que desconsiderava as relações entre doença e condições de vida - predominava a imposição de normas e medidas de saneamento consideradas científicas pelos técnicos e burocratas. As descobertas da bacteriologia, a partir de Pasteur, no final do sé culo XIX, tinham difundido a confiança na existência do conhecimento necessário para controlar as doençasinfecciosas, dando legitimidadecientífica às campanhas que se organizavam ${ }^{10}$.

A pesar da política de saúde pública apresentar o discurso da polícia sanitária, isto é, o propósito de introduzir através da força repressiva estatal normas e medidas de saúde, a função coerciva não visou simplesmente excluir, separar elementos desviantes. Como sugere M adel Luz, citada por Costa ${ }^{5}$, a função coercitiva no âmbito das instituições de saúde tem algo de educativo quando visa exemplar: pelo temor, aprende-se a ordem, a disciplina e, deste modo, a aceitar a hierarquia. Assim, essas ações estiveram inseparáveis de certo papel educativo-coercivo do Estado, que buscou realizar uma adequação entre 0 
aparato produtivo, a moralidade e os padrões de higiene das massas populares.

Em 1903, o médico O swaldo Cruz assumiu a Diretoria Geral deSaúde Pública, convidado pelo governo de Rodrigues Alves, com ênfase no saneamento urbano da cidade do Rio de Janeiro e combate às epidemias de febre amarela, peste e varíola ${ }^{11}$. Segundo Rosely M agalhães de Olivei$\mathrm{ra}^{8}$, Oswaldo Cruz passou a enfrentar as epidemias que grassavam a cidade do Rio de Janeiro através das brigadas sanitárias, compostas de mata-mosquitos, operários de limpeza pública, geralmente acompanhadas de soldados da polícia. Essas equipes percorriam as ruas e visitavam as casas, desinfetando, limpando, exigindo re formas, interditando prédios, removendo doentes. Visitavam obrigatoriamente todas as casas e removiam do seu interior tudo que fosse julgado

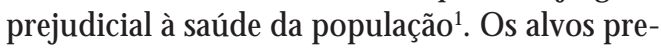
feridos das visitas eram, naturalmente, as áreas mais pobres e de maior densidade demográfica. Os quadros calamitosos de epidemias transformavam-se eventualmente em demandas políticas e pressionavam a ação estatal no âmbito da saúde, mas em nenhum instante, no entanto, se configurava a ideia de direito à saúdede ${ }^{1,6}$.

O Estado identificava até então a ignorância e a falta de informação da população como causa para a existência das doenças. Assim, a população era vista como a única causadora dos males de saúde que assolavam as grandes cidades. A educação em relação à saúde tinha papel marginal. Eram distribuídos folhetos avulsos, denominados Conselhos ao Povo, sobre os meios de evitar doenças ${ }^{1}$. Na verdade, a educação em saúde era breve porque, para as autoridades, o povo era incapaz de mai or entendimento e o discurso era muitas vezes para dizer quese tinha tentado a via do convencimento antes de ser "obrigado" a tomar iniciativas mais coercivas ${ }^{1}$.

A publicação de Euclides da Cunha de Os Sertões, em 1902, teve grande impacto nos círculos intelectuais das cidades brasileiras. Assim, vários escritores passaram a denunciar a falta de atenção do governo, preocupado apenas com o colono estrangeiro, cuja mão deobra era usada nas culturas cafeeiras, chamando a atenção para o valor econômico da produção do sertanejo e combatendo o latifúndio. Em uma primeira qualificação, o termo sertões passa a ser sinônimo de abandono, ausência de identidade nacional e difusão de doenças endêmicas ${ }^{11}$. A presença da doença causada pelo abandono das autoridades públicas, e não mais pela indolência, seria o elemento que explicaria 0 brasileiro, em especial sua improdutividade ${ }^{11}$.
Intelectuais da classe média das grandes cidades, mais independentes das oligarquias rurais, começaram a contestar a crença, até então dominante, de que a salvação nacional passava pela europeização e branqueamento da população através da imigração estrangeira e imposição de novos padrões de comportamento ${ }^{6}$ - movimento estedenominado de eugenismo, em que a educação se encarregava de domesticar e moralizar o proletariado urbano emergente e manter a raça rígida para construir a identidade do povo brasileiro ${ }^{3}$. Para os eugenistas, esta era a única alternativa que poderia limpar os brasileiros da nódoa do passado escravocrata e dos efeitos perniciosos da miscigenação, ou seja, o "sangue bom" permitira ao nosso povo redimir-se e purificar-se da contaminação de raças supostamente inferiores ${ }^{12}$.

Em contrapartida, parcelas da classe média passam a se unir com as classes populares, lutando por melhores condições de vida, sendo o fato mais marcante desta organização popular a chamada grande revolta, que se deu contra a campanha da vacinação obrigatória, em 1904, coordenada pelo médico Oswaldo Cruz. Pela primeira vez na história, as ações de saúde passaram do enfoque sobre o ambiente para a pessoa, sobre o corpo ${ }^{1}$. 0 ápice deste movimento se deu com a criação da Liga contra a vacinação obrigatória, com grande participação popular. Segundo Eymard M ourão Vasconcelos ${ }^{1}$, durante um comício no Largo de São Francisco, a cavalaria do exército cercou o prédio e carregou sobre os manifestantes, deixando muitos feridos e presos. Para 0 autor ${ }^{1}$, a importância deste episódio foi mostrar que as classes populares e médias urbanas, se ainda eram incapazes de participar da orientação das políticas públicas de saúde, eram capazes de se estruturar e já tinham evoluído na sua organização e cultura a ponto de poder resistir ao autoritarismo das oligarquias.

M onteiro Lobato, expressando um clamor emergente nas grandes cidades, assume em 1918 a bandeira deluta "sanear égrandequestão nacional" ${ }^{\prime}$. 0 problema brasileiro não estava na raça, mas nas doenças quetornavam a população preguiçosa e sem iniciativa13: o "Jeca não éassim, ele está assim", um caipira doente e por isso preguiçoso, pobre e atrasado que, ao passar a acreditar na medicina e seguir suas prescrições, livra-se da opilação e torna-se um fazendeiro saudável ${ }^{11}$. Dessa forma, as ações médicas e a educação assumem importância central no debate político nacional, surgindo várias campanhas e serviços voltados para o saneamento dos sertões no final 
da Primeira República ${ }^{6,11}$. No entanto, a falta de participação popular ainda era marcante e, se a população não era mais cul pada pela situação de subdesenvolvimento, ela continuava sendo vista como incapaz de mai ores entendimentos. N esta época, mantém-seo modelo de educação em saúde denominado por Eymard M ourão Vasconce$10 s^{6}$ de toca boiada: se antes se preocupava em tocar a boiada com o ferrão da polícia sanitária, agora era com o berrante, ou seja, com as palavras dos educadores sanitários.

Enfim, atéa década de vinte, a estrutura sanitária brasileira era caracterizada pela criação de unidades especializadas para fazer frente a problemas específicos. As ações focais dos serviços de saúde mostravam impacto no controle de algumas doenças como a febre amarela; no entanto, esse mesmo êxito das campanhas não era observado quando o problema dizia respeito às doenças menosagudas, como tuberculose, amplamentedistribuídas na populaçãa ${ }^{8}$. 0 sucesso dasações era considerado apenas parcial, pois a medicina logrou muito diagnóstico e pouca prevenção apenas al gumas vacinas foram desenvolvidas nos primeiros anos e quase nenhuma terapêutica eficaz, principalmente do ponto de vista coletivo ${ }^{10}$.

Entretanto, o fortalecimento econômico do complexo cafeeiro e o processo de industrialização fez surgir neste período uma nova concepção de serviços de saúde, denominada saúde pública. Junto com essa concepção, surge uma nova prática de educação voltada para a saúde, denominada educação sanitária - amplamente influenciada pela estrutura norteamerican ${ }^{8}$. Segundo Emerson Elias M erhy ${ }^{14}$, no interior da política de saúde, aumentou a crítica ao modelo anterior, como sendo de baixa eficácia diante dos novos problemas que a saúde pública tinha à sua frente, sendo que esses novos problemas agora eram a saúde da criança, dos trabalhadores, entre vários outros, aos quais só a higienee a educação sanitária poderiam responder. Houve assim um esgotamento da teoria unicausal da medicina, queexplicava as doenças apenas pelos agentes microscópicos, pois a incapacidade de responder a muitos fenômenos de morbidade e mortalidade populacional foi fatal para sua existência ${ }^{10}$. Entretanto, o movimento sanitarista, nessa época, continuava a ser fundamentalmente um movimento de elite, com uma pequena vista de olhos para a população, quepouco fez além dedistribuir exemplares da história de Jeca Tatuzinho, num país que contava, em 1920, com $70 \%$ de analfabetos ${ }^{12}$.

Em 1923, Carlos Chagas processou a primeira reforma sanitária brasileira, criando o Depar- tamento N acional de Saúde, então ligado ao M inistério daJ ustiça, ea educação sanitária e a propaganda foram introduzidas na técnica rotineira das ações em saúde, inovando o modelo campanhista de $\mathrm{O}$ swaldo $\mathrm{Cruz}$, que era puramente fiscal e policial ${ }^{15}$. Nesse processo, também foram criados, na Capital Federal, os primeiros centros desaúdebrasileiros. Estes centros se constituíam no interior da saúde pública como o local em que as ações sanitárias deveriam se dar. No sistema de ensino, a educação sanitária deveria ser assumida pelas escolas 3 . A educação sanitária surge com um papel de substituir os métodos repressivos das campanhas sanitárias pela persuasão e conscientização dos métodos educativos e preventivos junto a indivíduos e coletividades$^{3}$. Este modelo baseava-se na visão de que as doenças não eram só produzidas pelo meio externo, mas também pela consciência sanitária das pessoas. Muitas destas ideias foram trazidas ao país por jovens sanitaristas que iam até os Estados Unidos complementar sua formação médica e, ao voltarem, tentavam impo-las de forma extremamente autoritária ${ }^{16}$.

Com a difusão do ideário da Escola Nova, em que a criança era considerada o centro de tudo, e os avanços da biologia e da psicologia, as crianças e adolescentes passaram a ser a população preferencial a receber, através das escolas e postos de saúde, os princípios da higiene para manterem-sesaudáveis. Esta nova estrutura veio retirar a autoridade de polícia sanitária eas ações de educação em saúde passaram a se desenvolver pelos edu cadores sanitários e professoras, que eram treinados para exercerem a função de educar a população escolar. A padronização das informações e do desempenho dos técnicos era desejável pelos serviços, que se valiam de cursos de formação dos educadores com ênfase no uso de equipamentos e materiais de comunicação e da repetição das mesmas falas em qualquer lugar onde estivessem ${ }^{17}$. A visão positivista subjacente baseava-se na hipótese de que a instituição educacional poderia corrigir, através da higiene, a ignorância familiar que comprometia a saúde da criança e, portanto, as escolas seriam, além de espaço de ensino e controle social, espaços terapêuticos, recaindo sobre o professor a tarefa de transformar o mundo ${ }^{2}$. Baseado nestes pressupostos, iniciou-se o curso de educação sanitária na Faculdade de H igienee Saúde Pública daUniversidadede São Paulo (USP). 0 curso era dirigido principalmente para professores do ensino primário, voltado para a veiculação de mensagens de higiene no universo escolar ${ }^{18}$, e o proces- 
so saúde-doença era analisado apenas sob a ótica de disciplinas biologicistas ${ }^{19}$.

Porém, houve uma grande falha na proposta da década de vinte, quefoi o pequeno peso conferido aos fatores ambientais e ainda a excessiva importância aos agentes etiológicos. As ações não intervinham nas condições de vida e de trabal ho a que as populações infantis da classe popular estavam submetidas. As influências do mecanicismo e do positivismo foram bastante visíveis, sendo o contexto muito mais próximo de uma unicausalidade esclarecida, que aceitava a influência dos outros fatores, do que de uma multicausalidade de fato ${ }^{10}$. Assim, foram lançadas as bases para a estruturação dos serviços de saúde que se consolidariam, a partir de 1930, com a Era Vargas.

A falta de participação popular nos serviçose os modos coercivos, discriminatórios e autoritários como se deram as campanhas de saúde pública foram fundamentais para explicar os modelos de atenção à saúde, expandidos durante a Era Vargas, pois as classes populares passaram a encarar as práticas de educação em saúde com certa reserva ${ }^{8}$. A partir da década detrinta, a ação estatal no setor de saúde se concentra na construção de um sistema previdenciário destinado às categorias de trabalhadores mais organizadas politicamente e ações de caráter col etivo foram esvaziadas em favor da assistência médica individual. As ações educativas em saúdeficaram restritas a programas e serviços destinados às populações à margem do jogo político central, continuando a priorizar o combate das doenças infecciosas e parasitárias ${ }^{6}$.

Neste período, as ações de saúde passaram a se concentrar em campanhas sanitárias e programas especiais, como materno infantil e pronto-socorro, além de serviços especiais de saúde mental, entre outros, para onde recorriam as camadas da população que não podiam pagar ou que não estavam incluídas na assistência previdenciária ${ }^{20}$.

$\mathrm{N}$ a década de quarenta, em plena guerra, 0 governo brasileiro, em convênio com o americano, estrutura o Serviço Especial de Saúde Pública (SESP), que se tornou um dos marcadores do desenvolvimento dasinstituições de saúdeno país, particularmente por suas propostas no campo das programações de saúde ${ }^{14}$. Com 0 comando de militares norte-americanos, como parte do acordo para exploração de borracha e minérios do solo brasileiro, em 1942, unidades do SESP são organizadas primeiramente na Região Amazônica e Vale do Rio Doce, significando para o Brasil a vinda de novas tecnologias de medicina preventiva e formas de gerenciamento instituci- onal. As ações do SESP visavam à proteção dos trabalhadores envolvidos na extração da borracha e de minério, mas também trouxe novas técnicas educacionais na área de saúde e recursos audiovisuais sofisticados de tendência tecnicista de educação ${ }^{21}$. Ainda assim, a população continuava a ser vista como passiva e incapaz deiniciativas próprias ${ }^{6}$.

A atuação do SESP baseou-se na criação de postos permanentes - centro de saúde e postos rurais - em várias regiões, incluindo M inas $\mathrm{Ge}$ rais e Espírito Santo, contratação de sanitaristas em tempo integral e de uma equipe auxiliar com laboratoristas, escriturários, médicos consultantes e visitadores, entre outros. As atividades do SESP davam-se a partir de programas que associavam doenças contagiosas, diagnóstico precoce e tratamento preventivo, educação sanitária, atividades de higiene em geral e organização científica em termos administrativos dos serviços públicos ${ }^{14,19}$. N essa época, inovações metodológicas e novas técnicas de ensino-aprendizagem são introduzidas nas práticas de educação em saúde, tais como a educação de grupos, os recursos audiovisuais e o desenvolvimento e organização de comunidades, desencadeando ideias de participação e mobilização de indivíduos nas ações de saúde, contrariando a política centralizadora e paternalista do Estado como um todo ${ }^{21}$. A educação não era só dirigida às crianças e jovens imaturos, considerados, até então, os únicos possíveis de serem educados. Começa-se a considerar que 0 adulto também era possível de sofrer um processo de mudança ${ }^{19}$.

A Fundação SESP influenciou de forma importante na introdução da ideologia do desenvolvimento e participação comunitária, educação de grupos e, ainda, na reforma do currículo da Faculdade de H igiene e Saúde Pública, introduzindo os fatores sociais, econômicos e culturais na maneira de perceber o processo saúdedoença no currículo de educação sanitária ${ }^{19}$.

Esse movimento introduziu nas escolas a educação sanitária, ainda com forte influência eugenista, onde se buscou a criação de técnicas de regulação e normatização ${ }^{4}$, visando criar um sistema fundamental de hábitos higiênicos, capaz de dominar, inconscientemente, toda a existência das crianças $^{18}$.

Após a Segunda Guerra M undial, a Organização das Nações Unidas (ONU ), caracterizada pela hegemonia dos países do Primeiro M undo, sugeriu o desenvolvimento comunitário como forma explícita de mobilizar as populações carentes contra a miséria ${ }^{8}$. 0 desenvolvimento comunitário 
foi usado como forma de intervenção social, informando eplanejando modos demodificar comportamentos e gerar mudanças culturais. Assim, a partir da década de cinquenta, um novo papel é atribuído à educação em saúde, esta então denominada de educação para a saúde 3 .

A proposta de participação popular surgiu numa tentativa de canalizar e mobilizar a população para atuar em áreas sociais restritas, buscando superar a marginalidadeem queseencontravam certas parcelas da população ${ }^{21}$. Na saúde, a participação popular inicialmentese expressou pela extensão da cobertura de serviços básicos, mas sem modificações nas suas estruturas, ou seja, não garantiam a qualidade e resolutividade dos serviços prestados. Nesta fase, proliferou o número de treinamento de voluntários de saúde, aumentaram os programas comunitários que empregavam mão de obra gratuita, em mutirão, para o saneamento básico e construção de postos de saúde. 0 termo participação foi, sabidamente, manipulado e utilizado para determinados programas, que utilizaram a força do trabalho da comunidade, "onde os próprios beneficiários passaram a ser mão de obra não pensante de uma medicina simplista, para os pobres"21. A pesar disto, a ampliação física dos serviços facilitou 0 acesso geográfico aos serviços de saúde, mas não reduziu o fosso cultural e social para a população a quem se destinava ${ }^{21}$.

Assim, a pedagogia da saúde entre os anos cinquenta e sessenta pautou-se por uma ideologia modernizadora que tinha por meta remover os obstáculos culturais e psicossociais às inovações tecnológicas de controle às doenças, a fim de manter o domínio estrutural da sociedade ${ }^{22}$.

Em 1964, aconteceu o gol pemilitar no Brasil, impondo aos brasileiros um regime autoritário de administração pública, culminando com a piora da saúde, principalmente da parcela mais carenteda população. 0 regimeautoritário trouxe como consequência imediata para as políticas de saúde no Brasil um total esvaziamento da participação da sociedade nos rumos da previdênci $a^{23}$. N esta época, a política de saúde imposta pelos militares voltou-se para a expansão de serviços médicos privados, especialmente hospitais, nos quais as ações educativas não tinham espaço significativo ${ }^{6}$. A perspectiva de participação da comunidade nos processos de educação em saúde nesta década visava mobilizar as populações a cooperarem com os agentes e serviços de saúde inaugurados nas zonas rurais e periferias urbanas ${ }^{22}$. O governo passou a comprar serviços de assistência médica e as condições dos brasileiros, expressas em diferentes indicadores, tornaramse ainda mais críticas $^{20}$.

A ampliação da rede de serviços, como antes se pensava, não possibilitou grandes melhoras no quadro de saúde da população. Passaram a coexistir doenças infecciosas e as crônico-degenerativas. Com um agravante para a população excluída das políticas públicas, obrigada a conviver simultaneamente com os dois tipos de agravos, caracterizando uma situação de profunda desigualdade social e de desgaste corporal ${ }^{8}$.

Enfim, atéa década de setenta, a educação em saúde no Brasil foi basicamente uma iniciativa das elites políticas e econômicas e, portanto, subordinadas aos seus interesses. Voltava-se para a imposição denormas e comportamentos por elas considerados adequados. Para os grupos populares que conquistaram maior força política, as ações de educação foram esvaziadas em favor da expansão da assistência médica individualizada ${ }^{6}$.

$M$ as o regime militar criou, contrariamente, condições para a emergência de uma série de experiências de educação em saúde ${ }^{6}$, o que significou uma ruptura com o padrão acima descrito. Os movimentos populares que haviam sido violentamentereprimidos pelos primeiros governos militares após a revolução de 1964 começam a se rearticular e a crescer a partir da década de setenta, reivindicando melhores condições de vida $a^{6,13}$. A insatisfação política da população com o regimeficou evidente com os resultados das eleições de novembro de 1974, com a vitória do M DB único partido de oposição que estava autorizado a seorganizar ${ }^{8}$. Essemovimento ficou conhecido como M ovimento da Reforma Sanitária, que se ampliou ainda mais com a incorporação de lideranças políticas sindicais populares e também parlamentares interessados na causa ${ }^{23}$.

No auge do regime militar, especialmente a partir de 1967, as práticas de educação voltadas para a saúde, até então denominadas educação sanitária, receberam a denominação de educação em saúde eas equipes da área passaram a ser constituídas por diversos profissionais de saúde, não só por educadores?.

As mais de duas décadas de regime militar ea inflação el evada deram sua contribuição para que - Brasil fosse considerado um dos países com maiores índices de desigualdades no mundo e que aqui se instalasse a crise do setor saúde ${ }^{24}$. A crise do setor saúde foi caracterizada pela insuficiência, descoordenação, má distribuiçãa, inadequação eineficácia aos serviços durantea $V$ Conferência N acional deSaúde, em 1975²0. Diante da ameaça de quebra da estabilidade social, o Esta- 
do brasileiro foi obrigado a preocupar-se mais com os problemas de saúde, educação, habitação e saneamento da população. M as a crise econômica já se iniciava, tornando escassos os recursos financeiros disponíveis ${ }^{13}$. Assim, foi preciso encontrar um modelo alternativo de assistência médica e a medicina comunitária, que já vinha sendo colocada em prática em outros países do mundo, logo se mostrou a mais adequada às necessidades políticas do momento ${ }^{13}$.

N esta época, a educação em saúde tornou-se obrigatória nas escolas brasileiras de ensino médio e fundamental (antigos primeiro e segundo graus) pelo artigo 7 da lei no 5.692/71, com 0 objetivo deestimular o conhecimento ea prática da saúde básica e da higiene nos escolares².

Ao lado dos movimentos populares urbanos queeclodiram no final dos anos setenta, emergiu também a insatisfação de diversos profissionais da rede de serviços e de intelectuais que estavam encurralados nos espaços acadêmicos ${ }^{8}$. No interior das universidades, onde alguns professores e técnicos tinham, em mãos, al guns estudos que denunciavam os efeitos do modelo econômico sobre a saúde da população e a irracionalidade do sistema de saúde então implantado, teve início uma profunda reflexão e grupos debatem princípios e estratégias para se criar um sistema de saúde que atendesse às realidades da população brasileira³. Assim, foram introduzidos no Brasil os princípios dos cuidados primários de saúde, baseados nas recomendações da Conferência de Alma-Ata ${ }^{3}$, dando uma nova direção às políticas de saúde, enfatizando a participação comunitária, a cooperação entre diferentes setores da sociedade e os cuidados primários de saúde em seus fundamentos conceituais ${ }^{7,18}$.

Desta forma, a emergência desse novo processo de prática médica não substituiu a medicina científica, quecontinuou a ocupar o seu espaço hegemônico deatendimento às demandas das categorias sociais privilegiadas ${ }^{1}$. Antes, viabilizoua ao completar um sistema de medicina de classes, ou seja, a medicina comunitária nasceu para cobrir um buraco na assistência, sendo considerada uma medicina de e para marginalizados, sejam urbanos ou rurais. E o espaço da medicina comunitária passa a ser o espaço dos marginalizados, ou seja, as áreas rurais e periurbanas ${ }^{25}$.

$\mathrm{N}$ esses serviços, os profissionais passam a conviver mais de perto com os problemas das classes populares, com a dinâmica do processo de cura e adoecimento e muitos começam a reorientar suas práticas, buscando maneiras mais globais para 0 enfrentamento dos problemas de saúde ${ }^{13}$. Entretanto, os recursos escassos fizeram com que a prática médica se tornasse muito limitada. Os baixos salários dos profissionais ea quase ausência de acompanhamento educativo os dejxou desmotivados enão adaptados às novas funções. Além disso, ocorriam constantes interferências de políticos nos serviços, que os transformavam em locais para se conseguir votos ${ }^{13}$.

Este pouco caso e a utilização el eitoreira dos novos serviços de saúde provocaram muitos descontentamentos entre os profissionais. Segundo Eymard MourãoVasconcelos ${ }^{6}$, associações de bairro, sindicatose comunidades eclesiais de base começaram a lutar pela mel horia destes serviços, surgindo um número crescente de experiências nas quais seus profissionais e os movimentos populares se aliaram na luta pela criação de uma medicina mais apropriada às classes populares. Sob descaso do Estado com os problemas populares, foram se configurando iniciativas de busca de soluções técnicas construídas com base no diálogo entre o saber popular e o saber científico. N esta época, o método educacional sistematizado por Paulo Freire constituiu-se como uma espécie de eixo de referência para a relação entre profissionais de saúde e as classes populares 6 . Abre-se assim o espaço para novas experiências no campo da educação em saúde, baseadas no método dialógico de Paulo Freire, configurando enfim a educação popular em saúde.

Diante disso, a participação de profissionais de saúde nas experiências de educação popular a partir dos anos setenta trouxe para o setor de saúde uma cultura de relação com as classes populares que representou uma ruptura com a tradição autoritária e normatizadora da educação em saúde ${ }^{6,13}$. A educação popular em saúde, baseada numa relação dialógica entre o conhecimento técnico-científico e a sabedoria popular, caracterizada pela livre participação das classes populares com o direito e poder de pensarem, produzirem e dirigirem o uso de seus saberes a respeito de si próprias e de sua saúde, permitiu novos olhares, olhares estes que possibilitaram abordagens mais eficientes em defesa da saúdee da vida da população.

A segunda metade da década de oitenta foi marcada por uma profunda crise de caráter político, social e econômico, tendo enormes repercussões sobre a condição de saúde das populações, agravando as condições de vida, aumentando o desemprego, a desnutrição e a mobilidade dos grupos sociais menos protegidos ${ }^{8}$. A previdência, ao fim de sua fase de capitalização e com problemas de caixa oriundos de uma políti- 
ca que estimulava a corrupção eo desvio de verbas, apresentava-se sem capacidade para dar conta das demandas criadas $^{23}$. Cresceu, assim, 0 movimento social que defendia a democratização da saúde e difundia a proposta da reforma sanitária ${ }^{20}$, tendo como ponto alto de suas articulações a apresentação de suas propostas durante VIII Conferência Nacional de Saúde, em 1986, em Brasília. 0 momento propício com o advento da Nova República, pela eleição indireta de um presidente não militar, além da perspectiva de uma nova constituição, contribuíram para que esta conferência fosse considerada um marCo, um divisor das águas dentro do movimento pela reforma sanitária23.

O relatório da VIII Conferência Nacional de Saúde destacou, entre outras propostas, o conceito ampliado de saúde, a qual é colocada como direito de todos e dever do Estado. A saúde inte gral de cada indivíduo representa um fator para o desenvolvimento da nação em seu processo histórico. Com a incorporação de boa parte de suas propostas pela Assembléia Constituinte na elaboração da nova Carta M agna, a reforma sanitária brasileira concretizou suas ações no plano jurídico-institucional ${ }^{26}$. A queficou conhecida como Constituição Cidadã incluiu, no capítulo da seguridade social, a saúde como direito de todos e dever do Estado e moldou as diretrizes do Sistema Ú nico de Saúde, o SUS ${ }^{23}$. M as no momento em que foi promulgada, aprofundava-se a instabilidade econômica com a hiperinflação e crise fiscal do Estado, gerando sérios obstáculos à implantação da reforma sanitária. 0 recuo dos movimentos sociais, a disseminação da ideologia ne oliberal e a perda de poder aquisitivo dos trabaIhadores de saúde ensejaram uma operação de descrédito contra o SUS, seja por parte das classes dirigentes e mídia, seja pelas ações políticas predominantemente corporativas dos trabalhadores de saúde ${ }^{20,26}$. M esmo assim, o Congresso $\mathrm{Na}$ cional aprovou, em 1990, a Lei Orgânica da Saúde, sendo formada pelo conjunto deleisn $8.080 \mathrm{e}$ n` 8.142 de 1990. Decorridas mais de duas décadas, o SUS enfrenta ainda grandes desafios para a sua implantação efetiva. 0 modelo de assistência proposto, de caráter universal, vai de encontro à tendência econômica mundial para os países de América Latina, de corte de gastos na área social, como reflexo das políticas de ajuste definidas pelos organismos financeiros internacionais, entre eles o Fundo M onetário Internacional (FMI) e o Banco M undial20,26. M as, apesar das contradições e alguns impedimentos de ordem prática, a população conquistou o direito à saúde e à partici- pação social e, hoje, criam-se alternativas para que as diretrizes dos SUS (universalidade, equidadeeintegralidade) sejam efetivamenteimplantadas e alcancem o maior número de pessoas possível.

Vale destacar que a educação popular passou a ser um instrumento para a construção e ampliação da participação comunitária no gerenciamento e reorientação das políticas públicas durante o período de repressão militar ${ }^{6}$. Atualmente, configura no quadro de saúde brasileiro duas interfaces derelação educativa: a educação tradicional e a popular em saúde.

0 modelo tradicional hegemônico, fortemente influenciado pelo positivismo, centraliza o poder nos profissionais de saúde, que são detentores de todo o saber necessário para se ter uma vida saudável, ou seja, não se busca a autonomia mas, ao contrário, se enfraquece a população na medida em que prescreve educação de uma forma vertical. Esta educação preconiza a adoção de hábitos e persuasão dos indivíduos, que devem adotar comportamentos saudáveis, (deixar de fumar, aceitar a vacinação, ter práticas higiênicas, fazer exames preventivos, etc.) medianteo contato com veículos de comunicação em massa, como TV, cartazes e jornais, ou mesmo mediante 0 acesso às informações, propiciado pelo educador 27,28 . Assim, a educação em saúde sob esta perspectiva passa a promover uma tomada de decisão consciente por parte da população, que é informada sobre os riscos de certos comportamentos einteiramente responsável pela sua condição de saúde, num processo denominado por Victor Vincent Valla $a^{29}$ de culpabilização da vítima, ou seja, uma prática que permite esconder o mau funcionamento dos serviços públicos e o descompromisso dos governos. Do ponto devista histórico, vivese numa época em que a representação sobre a saúde e a vida saudável deslocou-se do âmbito do direito social para o de uma escolha individual.

Contrariamenteà educação tradicional, a educação popular em saúde se contrapõe ao autoritarismo da cultura sanitária e ao modo tradicional de definir técnica epoliticamenteintervenções na área de saúde, lutando pela transformação das relações de subordinação e de interlocução, em favor da autonomia, da participação das pessoas comuns e da interlocução entre saberes e práti$\operatorname{cas}^{30}$. A educação popular em saúde busca trabaIhar pedagogicamente o homem e os grupos envolvidos no processo de participação popular, fomentando formas coletivas de aprendizado e investigação, de modo a promover o crescimento da capacidadedeanálise crítica sobrea realidadee 
o aperfeiçoamento das estratégias de luta e enfrentamento. É uma estratégia de construção da participação popular no redirecionamento da vida social ${ }^{31}$. Seu método parte do pressuposto de que as classes populares têm uma dinâmica própria sobre as doenças eseus processos decura, adquirida no seu cotidiano e que este saber deve ser respeitado eincorporado às práticas de saúde. O corre em uma relação horizontal entre profissionais de saúde, considerados mediadores, ea comunidade, através de um diálogo educativo não-condutivista, acompanhado de um movimento para o fortalecimento comunitário, buscando criar relações sociais mais justas.

Pode-se afirmar que grande parte das experiências de educação popular em saúde está hoje voltada para a superação do fosso cultural existente entre os serviços de saúde, as organizações não-governamentais, o saber médico e mesmo as entidades representativas dos movimentos sociais, de um lado e, de outro, a dinâmica de adoecimento e de cura do mundo popular ${ }^{1}$. Há, contudo, uma mudança no foco dos destinatários (pobres, classes populares) para o processo de empoderamento, pelo qual os segregados e desiguais teriam condições de enfrentar as condições que geram exclusão ${ }^{32}$.

Ao se fazer um exame crítico abrangente da educação em saúde nas últimas décadas, destaca-se um desenvolvimento surpreendente euma reorientação crescente das reflexões teóricas e metodológicas. Entretanto, essas reflexões não vêm sendo traduzidas na prática dos serviços, acarretando um hiato entre teoria e prática ${ }^{28}$. A educação popular ainda é realizada sob a forma de ideologia, de impulso voluntário por parte de alguns profissionais que investem nela porque acreditam na sua força transformadora, não só para a vida dos indivíduos, mas para a organização global da sociedade. A prática hegemônica de educação em saúde ainda é a prescritiva, a tradicional. Nascida no espaço do descaso do governo e do sistema, a educação popular em saúde éhoje uma opção e não uma regra. A pesar de já ter ocorrido uma reorientação em muitos meios acadêmicos, com ampliação do espaço para discussão e experimentação de propostas quereorientem o modelo do atendimento no dia a dia dos serviços ${ }^{1}$, hoje, o maior desafio para a educação popular em saúde talvez seja a criação de uma nova hegemonia, uma hegemonia participativa, construindo uma tradição de formação de recursos humanos em saúde orientada pela educação popular ${ }^{1}$ em busca de uma cidadania compartilhada ${ }^{33}$.
O Quadro 1 propõe uma sistematização das informações obtidas sobre a trajetória da educação em saúde no Brasil.

\section{Consideraçõesfinais}

Como observado, os acontecimentos políticos afetam diretamente a educação em saúde. As intervenções do Estado no campo da educação e da saúde deram-se predominantemente em momentos de crise, com manifestações de insatisfação da população ou por ameaças ao setor financeiro. Inicialmente, as ações estatais de educação em saúde foram marcadas, assim como as intervenções assistenciais, por métodos coercivos, impostos pela polícia médica. A pós isto, com base na Escola N ova, essas ações passaram a se concentrar fundamentalmentenos escolares, com padronização das falas e dos consel hos ao povo, buscando sanear toda uma geração.

Com o golpe de 1964, o regime militar criou oportunidades para que se criassem alternativas técnicas, baseadas no diálogo com o saber popular, em busca do enfrentamento dos problemas de saúde das classes populares. Assim, surgiu, à margem da sociedade, sob o clima de embates políticos e ideológicos, a proposta do movimento sanitário brasileiro, aliado à educação popular em saúde, que no seu início foi marcada por uma resistência ao regime militar e ao sistema assistencial implantado.

Após a implantação do SUS, há diferentes movimentos articulando-se ao mesmo tempo, ou seja, ainda permanece a educação tradicional, centrando o poder nas mãos do profissional de saúde, e a educação popular, que no início era considerada como método alternativo de prática educativa. M as a educação popular em saúde sai enfim da margem da sociedade e incorpora outras práticas e espaços educativos, na busca do empoderamento por parte da comunidade, baseando-se no encorajamento e apoio, para que as pessoas e grupos sociais assumam maior controle sobre sua saúde e suas vidas.

Entretanto, apesar do grande desenvolvimento edeuma reorientação crescenteno campo das reflexões teóricas e metodológicas da educação em saúde, o mesmo não vem ocorrendo na prática dos serviços. Talvez um dos grandes desafios seja a formação de uma nova hegemonia representada por recursos humanos de formação orientada pela educação popular e respeito aos saberes da comunidade, em busca de uma verdadeira cidadania compartilhada. 
Quadro 1. Sistematização sobre a trajetória da educação em Saúde no Brasil.

\begin{tabular}{|c|c|c|c|c|c|}
\hline Componentes & Até anos 20 & Anos 20 & Anos 50 & Anos 60 e 70 & $\begin{array}{c}\text { A partir } \\
\text { dos anos } 80\end{array}$ \\
\hline $\begin{array}{l}\text { Designação das } \\
\text { práticas educativas } \\
\text { em saúde }\end{array}$ & $\begin{array}{l}\text { Não } \\
\text { configurada. }\end{array}$ & $\begin{array}{l}\text { Educação } \\
\text { sanitária. }\end{array}$ & $\begin{array}{l}\text { Educação para } \\
\text { a saúde. }\end{array}$ & $\begin{array}{l}\text { Educação em saúde } \\
\text { pública ou } \\
\text { educação em saúde. }\end{array}$ & $\begin{array}{l}\text { Educação em } \\
\text { saúde e educação } \\
\text { popular em saúde. }\end{array}$ \\
\hline $\begin{array}{l}\text { Evento(s) que } \\
\text { influenciou(aram) a } \\
\text { metodologia aplicada } \\
\text { em tais práticas }\end{array}$ & $\begin{array}{l}\text { Relatório } \\
\text { Flexner. } \\
\text { Bacteriologia de } \\
\text { Pasteur. }\end{array}$ & $\begin{array}{l}\text { Primeira } \\
\text { reforma } \\
\text { sanitária } \\
\text { brasileira. }\end{array}$ & $\begin{array}{l}\text { Chega ao } \\
\text { Brasil a } \\
\text { Fundação } \\
\text { SESP (novas } \\
\text { tecnologias } \\
\text { educativas). }\end{array}$ & $\begin{array}{l}\text { Golpe militar no } \\
\text { Brasil. } \\
\text { Conferência de } \\
\text { Alma-Ata, } \\
\text { projetos de } \\
\text { medicina } \\
\text { comunitária e } \\
\text { cuidados primários } \\
\text { em saúde. }\end{array}$ & $\begin{array}{l}\text { VIII Conferência } \\
\text { Nacional de Saúde } \\
\text { e a consolidação } \\
\text { da Constituição } \\
\text { Cidadã. }\end{array}$ \\
\hline $\begin{array}{l}\text { Local ou espaços de } \\
\text { atuação }\end{array}$ & $\begin{array}{l}\text { Residências, } \\
\text { ruas elocais } \\
\text { públicos. }\end{array}$ & $\begin{array}{l}\text { Centros de } \\
\text { saúde, escolas e } \\
\text { lares. }\end{array}$ & $\begin{array}{l}\text { Escolas, locais } \\
\text { de trabalho e } \\
\text { comunidades } \\
\text { rurais. }\end{array}$ & $\begin{array}{l}\text { Serviços de saúde e } \\
\text { escolas. }\end{array}$ & $\begin{array}{l}\text { UBS, escolas, } \\
\text { conselhos e } \\
\text { espaços } \\
\text { comunitários. }\end{array}$ \\
\hline População- alvo & Elite urbana. & $\begin{array}{l}\text { Famílias e } \\
\text { escolares. }\end{array}$ & $\begin{array}{l}\text { População } \\
\text { urbana e rural } \\
\text { de todas as } \\
\text { idades. }\end{array}$ & $\begin{array}{l}\text { Escolares e grupos } \\
\text { específicos. }\end{array}$ & Toda a população. \\
\hline Quem era o educador & Polícia sanitária. & $\begin{array}{l}\text { Educador } \\
\text { sanitário e } \\
\text { professoras. }\end{array}$ & $\begin{array}{l}\text { Educador } \\
\text { sanitário e } \\
\text { profissionais } \\
\text { de saúde. }\end{array}$ & $\begin{array}{l}\text { Equipes de saúde } \\
\text { multiprofissionais. }\end{array}$ & $\begin{array}{l}\text { Todos envolvidos, } \\
\text { incluindo a } \\
\text { população. }\end{array}$ \\
\hline $\begin{array}{l}\text { Atribuições do } \\
\text { educador }\end{array}$ & Fiscalização. & $\begin{array}{l}\text { Divulgar o saber } \\
\text { médico, } \\
\text { higienista e } \\
\text { convencer as } \\
\text { camadas } \\
\text { populares a } \\
\text { seguirem certos } \\
\text { padrões de } \\
\text { comportamento. }\end{array}$ & $\begin{array}{l}\text { Práticas de } \\
\text { intervenção } \\
\text { social, } \\
\text { informar e } \\
\text { planejar } \\
\text { modos de } \\
\text { modificar o } \\
\text { comportamento } \\
\text { e gerar } \\
\text { mudanças } \\
\text { culturais. }\end{array}$ & $\begin{array}{l}\text { Capacitar o } \\
\text { educando para o } \\
\text { autocuidado. }\end{array}$ & $\begin{array}{l}\text { Buscar junto com } \\
\text { a população } \\
\text { propostas de } \\
\text { solução dos } \\
\text { problemas. }\end{array}$ \\
\hline Papel do educador & Controlador. & $\begin{array}{l}\text { Divulgadore } \\
\text { comunicador. }\end{array}$ & Interventor. & Treinador. & Mediador. \\
\hline $\begin{array}{l}\text { Atividades } \\
\text { desenvolvidas pelos } \\
\text { profissionais da } \\
\text { educação em saúde }\end{array}$ & $\begin{array}{l}\text { Propaganda } \\
\text { sanitária } \\
\text { (conselhos ao } \\
\text { povo). } \\
\text { Fiscalização } \\
\text { sanitária. }\end{array}$ & $\begin{array}{l}\text { Palestras, } \\
\text { conferências e } \\
\text { produção de } \\
\text { impressos. }\end{array}$ & $\begin{array}{l}\text { Educação de } \\
\text { grupose } \\
\text { trabalhos em } \\
\text { equipe. } \\
\text { Incentivo à } \\
\text { participação } \\
\text { comunitária } \\
\text { para suprir } \\
\text { carências do } \\
\text { governo. }\end{array}$ & $\begin{array}{l}\text { M etodologia } \\
\text { centrada no } \\
\text { educador ou } \\
\text { profissional, que } \\
\text { passa informações } \\
\text { sobre o } \\
\text { autocuidado à } \\
\text { população. }\end{array}$ & $\begin{array}{l}\text { Educação } \\
\text { tradicional é ainda } \\
\text { hegemônica, mas a } \\
\text { metodologia } \\
\text { participativa, } \\
\text { baseada no diálogo } \\
\text { com as classes } \\
\text { populares, ganha } \\
\text { espaço formal nas } \\
\text { universidadese } \\
\text { políticas de saúde. }\end{array}$ \\
\hline
\end{tabular}

Fonte: Baseado no trabalho deDias Gonçalves Rocha ${ }^{34}$. 


\section{Colaboradores}

CMC Silva e FL Mialhe contribuíram para a re visão bibliográfica e concretização do artigo. MC Meneghim e AC Pereira contribuíram para o aprofundamento da reflexão e revisão do texto.

\section{Referências}

1. Vasconcelos EM. Participação popular e educação nos primórdios da saúde pública brasileira. In: Vasconcelos EM, organizador. A saúde nas palavras e nos gestos: reflexões da rede educação popular e saúde. São Paulo: Hucitec; 2001. p. 73-99.

2. Mohr A, Schall VT. Rumos da educação em saúde no Brasil e sua relação com a educação ambiental. Cad Saude Publica 1992; 8(2):199-203.

3. Rocha DG. Análise do comportamento educativo nos programas preventivos em saúde bucal no Brasil, 1980 - 1994 [tese]. São Paulo (SP): Universidade de São Paulo; 1997.

4. Costa NR. Estado, educação e saúde: a higiene da vida cotidiana. Cad. Cedes 1980; 4:5-27.

5. Costa NR. Lutas urbanas e controle sanitário: origens das políticas de saúde no Brasil. Petrópolis: Vozes; 1985.

6. Vasconcelos EM. Educação popular e a atenção à saúde da família. São Paulo: Hucitec; 1999.

7. Oliveira AGRC, Souza ECF. A saúde no Brasil: trajetórias de uma política assistencial. In: Universidade Federal do Rio Grande do Norte. Departamento de Odontologia. Odontologia preventiva e social: textos selecionados. Natal: EDUFRN; 1997. p. 114-125.

8. Oliveira RM . A produção do conhecimento em escala local: repensando a relação entre a investigação científica e a experiência dos grupos populares [tese]. Rio de Janeiro (RJ): Escola Nacional de Saúde Pública; 2000.

9. Fleury SMT. Notas sobre as políticas de saúde no Brasil de Transição Democrática - anos 80 . Physis 1991; 1(1):77-96.

10. Freitas SFT. História social da cárie dentária. Bauru: Edusc; 2001.

11. Hochman G. A era do sanitarismo. 2ª ed. São PauIo: Hucitec; 2006.

12. Santos LAC. O pensamento sanitarista na primeira república: uma ideologia da construção da nacionalidade. Rev Ciências Sociais 1985; 28(2):193-210.

13. Vasconcelos EM. Educação popular nos serviços de saúde. 2ª ed. São Paulo: Hucitec; 1991.

14. M erhy EE. A rede básica como uma construção da saúde pública e seus dilemas. In: M erhy EE, Onocko R, organizadores. Agir em saúde: um desafio para o público. 2a ed. São Paulo: Hucitec; 1997.

15. Polignano MV. Histórias das políticas de saúde no Brasil: uma pequena revisão. [site da Internet] [acessado 2007 abr 13]. Disponível em: http://internatorural. medicina.ufmg.br/saude_no_brasil.pdf

16. Lima ALGS, Pinto MMS. Fontes para a história dos 50 anos do Ministério da Saúde. Hist. cienc. saudeM anguinhos 2003; 10(3):1037-1051.

17. Figueiró AC. Pensando a prática de educação popular em saúde. Nós da Rede: Boletim da Rede de Educação Popular em Saúde 1999; 2:3-4.

18. Rocha HHP. Educação escolar e higienização da infância. Cad. Cedes 2003; 23(59):39-56.

19. M elo JAC. Educação Sanitária: U ma visão crítica. Cad. Cedes 1984; 4:28-43.

20. Paim JS. Políticas de saúde no Brasil. In: Rouquayrol MZ, Almeida Filho N, organizadores. Epidemiologia e saúde. 6a ed. Rio de Janeiro: Guanabara Koogan; 2003. p. 587-603. 
21. Rosa MSO. Saber e Participação Popular: diálogo e aprendizagem da cidadania em Saúde. Rev M unicípio Saúde 1994; 1(1):10-15.

22. Canesqui AM. Trajetória da educação popular nas instituições estaduais de saúde. In: Paiva V. organizador. Perspectivas e dilemas da educação popular. Rio de Janeiro: Graal; 1984. p. 315-324.

23. Roncalli AG. 0 desenvolvimento das políticas públicas de saúde no Brasil e a construção do Sistema Único de Saúde. In: Pereira AC, organizador. Odontologia em saúde bucal coletiva: planejando ações e promovendo saúde. Porto Alegre: Artmed; 2003. p. 28-49.

24. Valla VV. Globalização e saúde no Brasil: a busca da sobrevivência pelas classes populares via questão religiosa. In: Vasconcelos EM, organizador. A saúde nas palavras e nos gestos: reflexões da rede popular e saúde. São Paulo, Hucitec; 2001. p. 39-62.

25. Mendes EV. A evolução histórica na prática médica: suas implicações no ensino, na pesquisa e na tecnologia. Belo Horizonte, PU C-M G; 1984.

26. Roncalli AG. A organização da demanda em serviços públicos de saúde bucal: universalidade, equidade e integralidade em saúde bucal coletiva [tese]. Araçatuba (SP): Faculdade de Odontologia, Universidade Estadual Paulista; 2000.

27. Smeke ELM, Oliveira NLS. Educação em saúde e concepções de sujeito. In: Vasconcelos EM, organizador. A saúde nas palavras e nos gestos: reflexões da rede educação popular e saúde. São Paulo: Hucitec; 2001. p. 115-136.

28. Gazzinelli M F, Gazzinelli A, Reis DC, Penna CM M . Educação em saúde: conhecimentos, representações sociais e experiência da doença. Cad Saude Publica 2005; 21(1):200-206.

29. Valla VV. Sobre participação popular: uma questão de perspectiva. Cad Saude Publica 1998; 14(Supl. 2):718.

30. Stotz EM . Os desafios para o SU S e a educação popular: uma análise baseada na dialética da satisfação das necessidades de saúde. [site da Internet] [acessado 2007 mar 08]. Disponível em: http://www.redepopsaude. com.br

31. Vasconcelos EM. Educação popular, um jeito especial de conduzir o processo educativo no setor saúde. [site da Internet] [acessado 2007 mar 08]. Disponível em: http://www.redepopsaude.com.br

32. Streck DR. A educação popular e a (re)construção do público: há fogo sobre as brasas? Rev. Bras. Educ. 2006; 11(32):272-284.

33. Souza, ES. Educação popular e saúde: cidadania compartilhada. In: Vasconcelos EM, organizador. A saúde nas palavras e nos gestos: reflexões da rede educação popular e saúde. São Paulo: Hucitec; 2001. p. 30-32.

34. Rocha DG. Análise do componente educativo nos Programas Preventivos de Saúde Bucal no Brasil, 1980 1994 [dissertação]. São Paulo (SP): Faculdade de Saúde Pública, USP; 1997.

Artigo apresentado em 30/05/2007

Artigo aprovado em 16/10/2007

Versão final apresentada em 14/12/2007 